\title{
Comparison of Automated and Manual DNA Isolation Methods of Liquid-Based Cytology Samples
}

\author{
Irma G. Domínguez-Vigil,,2 Víctor H. Barajas-Olmos, Lenny Gallardo-Alvarado, ${ }^{3}$ \\ Antonio A. Pérez-Maya, Maria L. Garza-Rodríguez, ${ }^{4}$ Gerardo I. Magallanes-Garza, ${ }^{5}$ \\ Servando Cardona-Huerta, ${ }^{5}$ Daniel H. Méndez-Lozano, ${ }^{6}$ Oscar Vidal-Gutiérrez, ${ }^{4}$ \\ David F. Cantú De León, ${ }^{3}$ and Hugo A. Barrera-Saldaña ${ }^{1,7,8}$
}

Liquid-based cytology (LBC) has been used as a diagnostic tool for cervical cancer for years and is now being adopted for other gynecological cancers. LBC represents an important challenge to ensure that the process yields representative biospecimens for quality control (QC) of diagnostic procedures. In this study, we compare QC parameters (integrity, yield and purity, and polymerase chain reaction [PCR] amplification) of DNA isolated from LBC $(N=296)$ using two different nucleic acid isolation methods, manual $(n=233)$ or automated $(n=63)$. We also evaluated two different types of cytological brushes for sampling from the cervix. Our results suggest that manual isolation (yield $22.81 \pm 1.92 \mu \mathrm{g}$ ) resulted in increased DNA recovery when compared with automated isolation (yield $9.96 \pm 1.11 \mu \mathrm{g}$ ) from LBC samples, with a $p$-value of $<0.0003$. We estimated that $98 \%(53 / 54)$ of the samples preserved the integrity of DNA and were suitable for standard molecular biology analyses. The $\beta$-globin gene was amplified in 100\% (296/296) of the DNA samples by endpoint PCR. We found no significant difference between the performance of the cytological brushes $(p$ value of $<0.6711$ ) in a general overview. However, when looking at the results from using each brush individually, the manual isolation method was statistically superior to the automated method. Our work illustrates the impact of good QC of preanalytic conditions, which will be important for the application of LBC for developing early detection methods for gynecological cancers.

Keywords: cervical cancer, liquid-based cytology, nucleic acids, quality control, biobank, biomarker

\section{Introduction}

$\mathrm{T}$ He PaP SMEar Has been a highly effective screening tool in the diagnosis of cervical cancer $(\mathrm{CC})^{1}$ since its development by George Papanicolaou more than 70 years ago. ${ }^{2}$ More recently, this technique has been modified into a liquid-based Pap smear or liquid-based cytology (LBC) to improve early detection, reduce false-negative rates, and simplify quality control (QC) that is demanded by conventional cervical cytology. ${ }^{3}$ These modifications also offer advantages extending to multiple slide preparation, the in- corporation of special stains (immunohistochemistry), human papillomavirus (HPV) detection through DNA testing, ${ }^{1}$ and even the potential to detect other gynecological malignancies, most notably, endometrial and ovarian cancers.,

QC represents an important challenge in ensuring representative biospecimens for diagnostic purposes and is a prerequisite for performing biomarker discovery. ${ }^{6,7}$ Currently, the scientific community is not focused solely on the final results of investigations based on biospecimens but is more concerned with preanalytical conditions. ${ }^{8} \mathrm{QC}$ in both the preanalytical and analytical phases is critical to guarantee reproducible and

\footnotetext{
${ }^{1}$ Departamento de Bioquímica y Medicina Molecular, Facultad de Medicina, Universidad Autónoma de Nuevo León, Monterrey, NL, Mexico.

${ }^{2}$ Laboratory for Translational Research, Rudy L. Ruggles Biomedical Research Institute, Western Connecticut Health Network, Danbury, Connecticut.

${ }^{3}$ Subdireccion de Investigación Clínica, Instituto Nacional de Cancerología, Ciudad de México, Mexico.

${ }^{4}$ Servicio de Oncología, Hospital Universitario “Dr. José Eleuterio González," Universidad Autónoma de Nuevo León, Monterrey, Nuevo León, Mexico.

${ }^{5}$ Tecnologico de Monterrey, Hospital San José, Monterrey, NL, Mexico.

${ }^{6}$ Tecnologico de Monterrey, Hospital Zambrano Hellion, San Pedro Garza García, NL, Mexico.

${ }^{7}$ Mexican Biobanks Network at Vitagénesis, SA.

${ }^{8}$ National Laboratory of Specialized Services of Research, Development, and Innovation for Chemical and Biotechnological Drugs at Innbiogem, SC, Monterrey, Mexico.

(C) Irma G. Domínguez-Vigil et al., 2019; Published by Mary Ann Liebert, Inc. This Open Access article is distributed under the terms of the Creative Commons License (http://creativecommons.org/licenses/by/4.0), which permits unrestricted use, distribution, and reproduction in any medium, provided the original work is properly cited.
} 
reliable results. Procedures have been developed to guarantee the quality of conventional biopsies, such as blood (including plasma and serum), saliva, cerebrospinal fluid, synovial fluid, urine, semen, and surgical tissues.

The field of gynecologic oncology is now poised to experience a further diagnostic revolution following the seminal work of Kinde et al., who merged next-generation sequencing (NGS) with LBC for early disease detection. ${ }^{4}$ Since LBC is a noninvasive sampling method with minimal inconvenience for the patients, it offers advantages over more invasive methods, with the overarching potential of using LBC as a preliminary material for biomarker discovery/ validation in endometrial and ovarian cancers.

The objective of this study was to compare QC parameters of the DNA extracted and purified from LBC samples obtained using two types of cervical brushes in common use and treated with two different nucleic acid isolation methods.

\section{Materials and Methods}

\section{Patient enrollment and consent}

All women were invited to participate in the research project and an interview was performed. Once the patients agreed to participate, an informed consent form was signed and study enrollment proceeded. All LBC samples were collected over a 2-year period from July 2015 to September 2017 according to protocols approved by the Institutional Ethical and Research Committees of the participants' respective institutes (Facultad de Medicina y Hospital Universitario "Dr. José E. González" [HU] de la Universidad Autónoma de Nuevo Leon [UANL], registration number BI13005; Instituto Nacional de Cancerología [INCan], registration number CEI/1031/16; and San José [HSJ] and Zambrano Hellion [HZH] Hospitals of Tecnologico de Monterrey, registration number 3CEI190390139).

\section{Sample collection}

Cervical sampling was performed by experienced gynecologists and nurses belonging to the staff of their respective institutes using either of two types of brushes available at the time in the clinical settings: (a) Colpotre ${ }^{\circledR}$ (Uileben, Mexico City, Mexico) $(n=261)$, with the cells collected by five clockwise rotations $\left(360^{\circ}\right)$, and (b) Rovers ${ }^{\circledR}$ CervexBrush-Combi (Puritan, Guilford, ME) $(n=35)$, with the cells collected by two clockwise rotations $\left(360^{\circ}\right)$. Both preparations of brush-collected cells were immediately transferred into a $50 \mathrm{~mL}$ conical tube $\left(\mathrm{CORNING}^{\circledR}\right.$, San Nicolas de los Garza, Nuevo Leon, Mexico) containing $7.5 \mathrm{~mL}$ of PreservCyt $^{\circledR}$ solution (ThinPrep ${ }^{\circledR}$; Hologic ${ }^{\circledR}$, Marlborough, MA) for nucleic acid suspension and preservation. All samples were stored at $4^{\circ} \mathrm{C}$ until processed for nucleic acid isolation within the following 1-52 days. Samples from INCan (Mexico City, Mexico) were transported to the laboratory at the Departmento de Bioquímica y Medicina Molecular at the UANL (Monterrey, Mexico) in a cooler container with gel packs by priority shipping such that delivery occurred within 24 hours (FedEx, Mexico City, Mexico) with an average of 10 LBCs (range 5-15) per shipment.

\section{DNA isolation}

Each sample was vortexed for 30 seconds, centrifuged at $300 \mathrm{~g}$ for 10 minutes at $4^{\circ} \mathrm{C}$, and the supernatant was dis- carded. The pelleted cells were lysed by adding $600 \mu \mathrm{L}$ of lysis buffer RLT Plus (Qiagen ${ }^{\circledR}$, Hilden, Germany) (cells were counted to establish the amount of RLT Plus buffer) and homogenized for 30 seconds with a TissueRuptor ${ }^{\mathrm{TM}}$ (Qiagen) at medium velocity. Each sample was extracted by either a manual or an automated (Qiacube ${ }^{\mathrm{TM}}$; Qiagen, Germantown, MD) method available at the time, following in both cases the protocol of AllPrep DNA/RNA/microRNA Universal $\mathrm{Kit}^{\mathrm{TM}}$ (Qiagen) as indicated in Figure 1, using $600 \mu \mathrm{L}$ of homogenized lysate as a starting material. Both manual and automated extractions were performed in the same laboratory and the DNA quantified on the same instrument. Purified nucleic acids were eluted in $100 \mu \mathrm{L}$ initially, and a second backup elution with an extra $50 \mu \mathrm{L}$ from the final step of the protocol was biobanked in $1 \mathrm{~mL}$ special DNAse and RNAse free cryotubes (Nunc ${ }^{\mathrm{TM}}$; Thermo ${ }^{\circledR}$, Waltham, MA). The data from QC were generated from the first $100 \mu \mathrm{L}$ eluted nucleic acids.

\section{$Q C$ of DNA}

DNA was analyzed for integrity, yield, and purity. Suitability of DNA for gene variation analysis was further analyzed by using it as a substrate for amplification of a region of the $\beta$ globin gene by endpoint polymerase chain reaction (PCR).

Integrity of DNA. The integrity was analyzed by agarose gel electrophoresis. For this purpose, up to $400 \mathrm{ng}$ of DNA, quantified by spectrophotometer, was used and the average size (as an index of integrity) was estimated using a 100 base pairs (bp) DNA ladder (Promega ${ }^{\circledR}$, Fitchburg, WI, and Invitrogen $^{\mathrm{TM}}$, Waltham, MA).

Measurement of DNA yield and purity. DNA yields were quantified by using a Qubit ${ }^{\circledR} 2.0$ Fluorometer, with the Qubit ${ }^{\mathrm{TM}}$ dsDNA BR Assay Kit for 292 of 296 samples and Qubit dsDNA HS Assay Kit for the rest of the four samples. Purity was judged by the $A_{260 n m} / A_{280 n m}$ and $A_{260 n m} / A_{230 n m} a b-$ sorbance ratios by using a UV-Vis NanoDrop ${ }^{\mathrm{TM}} 2000$ spectrophotometer (Thermo).

PCR amplification as a functional assay of DNA quality. The $\beta$-globin gene $(H B B)$ was amplified using GoTaq Colorless Master Mix (Promega), following the manufacturer's instructions. The reaction mixture of $0.2 \mu \mathrm{M}$ for each of the $\beta$-globin gene primers (forward: 5'-CAACTTCATCCACGTTCACC$3^{\prime}$ and reverse: 5'-GAAGAGCCAAGGACAGGTAC-3'; IDT, Skokie, IL), $100 \mathrm{ng}$ of DNA quantified by spectrophotometer (seven samples contained less than $100 \mathrm{ng}$ ), and GoTaq Colorless Master Mix. The reaction volume was adjusted with Milli-Q water to a final volume of $13.5 \mu \mathrm{L}$. After an initial denaturation step at $94^{\circ} \mathrm{C}$ for 5 minutes, amplification was carried out for 30 cycles, comprising each of the following successive steps of incubation at $94^{\circ} \mathrm{C}$ (denaturation) for 30 seconds, incubation (annealing) at $57^{\circ} \mathrm{C}$ for 30 seconds, and at $72^{\circ} \mathrm{C}$ (elongation) for 2 minutes. Cycling concluded with a final extension step at $72^{\circ} \mathrm{C}$ for 10 minutes. Amplification was performed using a Veriti Thermal Cycler (Applied Biosystems ${ }^{\circledR}$, Foster City, CA). The expected prominent PCR product of $268 \mathrm{bp}$ was confirmed following electrophoresis of amplification product in $2 \%$ agarose gel.

\section{Statistical analysis}

Considering the variables of brush types, isolation protocols used, and storage time before processing/nucleic acid isolation, we compared the yield based on fluorescence 


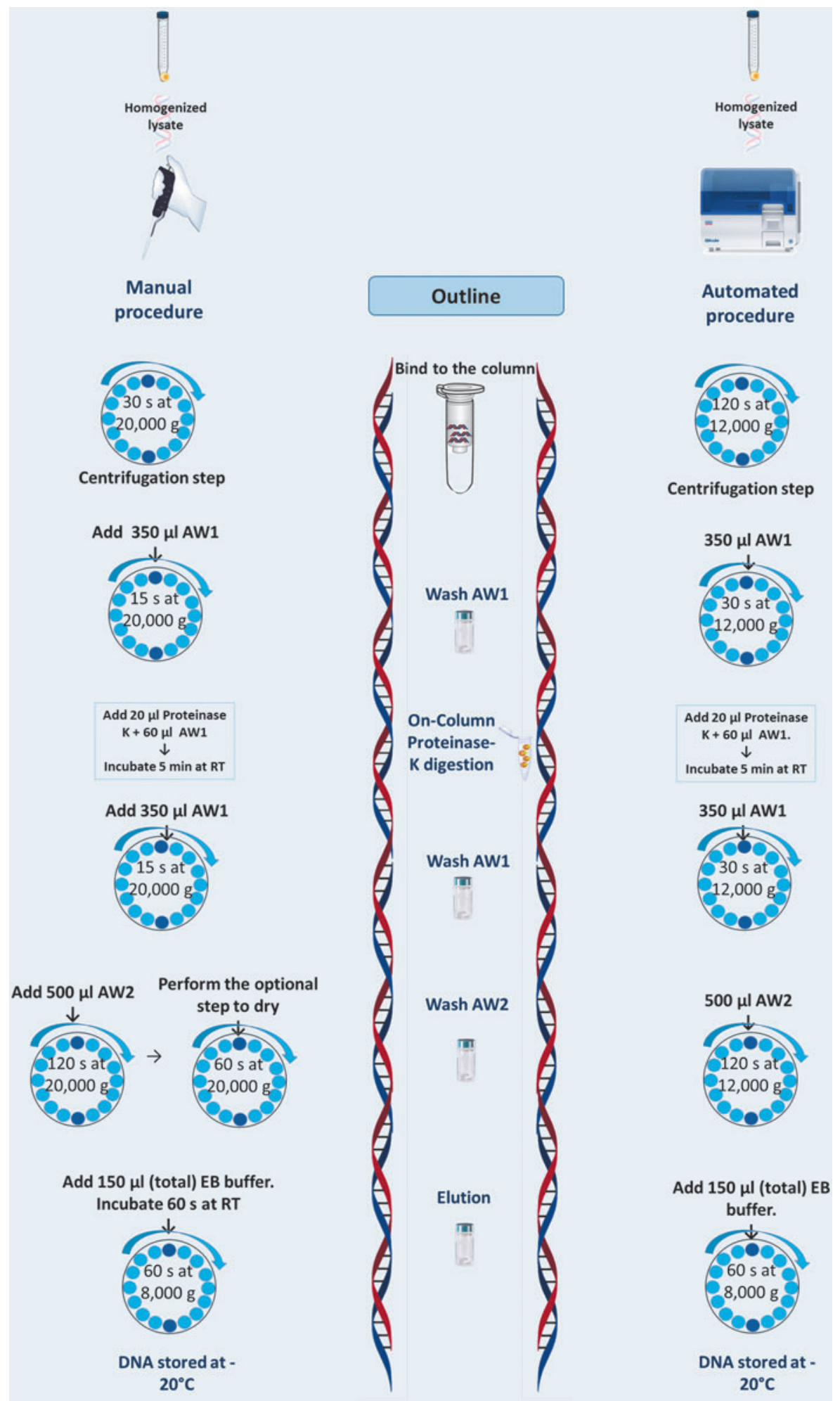

FIG. 1. Schematic representation of DNA procedure from LBC samples. Left side: manual procedure; middle: outline procedure; right side: automated procedure. $\mathrm{RT}=$ room temperature; $\mathrm{EB}=$ elution buffer; AW1 and AW2=buffer concentrate provided from AllPrep DNA/RNA/miRNA Universal Kit. LBC, liquid-based cytology. of dsDNA preparations. Quantitative results obtained were analyzed using the GraphPad Prism 5 Software package (GraphPad Software, Inc., La Jolla, CA). Data are presented as the mean \pm standard error of the mean. Unpaired data were compared using the unpaired Student's $t$-test. A $p$-value of $<0.05$ was considered significant. One-way analysis of variance was used to compare the yield of nucleic acids versus time until the isolation process.

\section{Results}

Two hundred ninety-six women were enrolled for this study, with a mean age of 49 ( \pm 13 standard deviation) years and range of 19-85 years. Sixty-one LBCs from participants were collected and processed within 24 hours. Two hundred thirty-five biospecimens from study participants at the other centers were collected, stored at $4^{\circ} \mathrm{C}$ for transport to our 
processing center. DNA from the samples was isolated by either manual $(n=233)$ or automated $(n=63)$ procedure as indicated in Figure 1. Samples were assigned to either processing procedure available at the time. Ninety-six percent $(226 / 235)$ of samples from out of town were processed between 1 and 35 days. Four samples were isolated at later time points, between 36 and 52 days.

\section{The integrity of DNA is suitable for standard molecular biology analyses}

DNA integrity was investigated by electrophoresis in $1 \%$ agarose gel and was judged by the proportion of highversus low-molecular-weight DNA as suggested by evidence of smearing (Fig. 2). Based on this qualitative assessment, it was estimated that $98 \%(53 / 54)$ of the samples tested were of sufficient quality.

\section{DNA yield from $L B C$ samples is more efficient by manual isolation}

The efficiency of DNA extraction was compared between the two isolation methods and the type of brushes (Rovers vs. Colpotre) used by evaluating their impact on the QC parameters of the characterized samples (Table 1). In this study, the manual isolation method resulted in increased DNA recovery when compared with the automated isolation method $\left(p<0.0003^{* * *}\right)$, regardless of the type of brush used: Colpotre $\left(p<0.0022^{* *}\right)$ or Rovers $\left(p<0.0445^{*}\right)$. Additionally, the variable of time between sample collection and processing was analyzed to determine if it impacted the nucleic acid yield from the PreservCyt solution-stored cells (Fig. 3). Most of the INCan samples, 71\% (168/235), were isolated within the 1-14 days after collection; the effect of the time in these samples' yield was not significant $(p<0.3128)$.

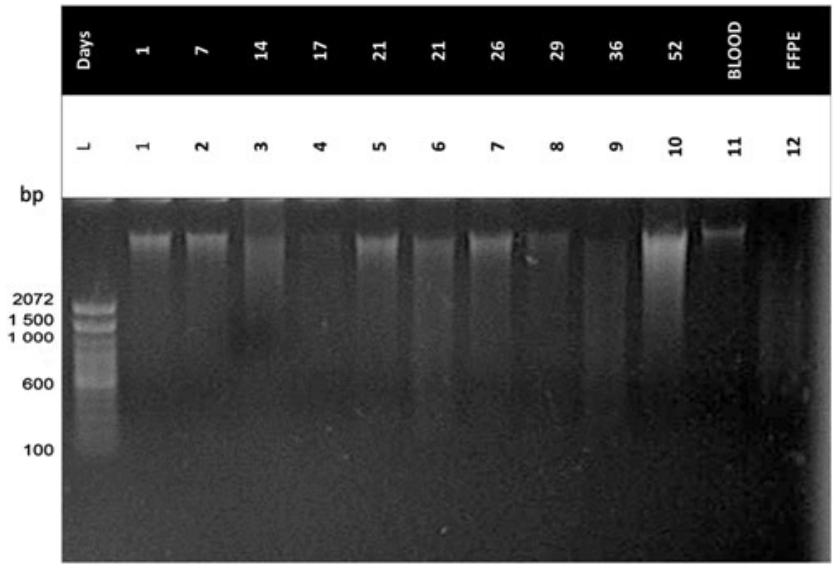

FIG. 2. Integrity assessment of isolated nucleic acids. Lane L: DNA ladder $100 \mathrm{bp}$; Lanes 1-10: DNA of LBC samples taken by Colpotre ${ }^{\circledR}$ and isolated by manual method; Lane 11: DNA of blood sample; Lane 12: DNA from formalin-fixed paraffin-embedded tissue; Conditions: $400 \mathrm{ng}$ of DNA in agarose gel at $1 \%$ at 110 volts during 60 minutes. First row indicates sample storage time (days) before isolate DNA.

\section{Amplifiability of DNA isolated from $\angle B C$ samples}

The 268 bp band of the $\beta$-globin gene was amplified in $100 \%$ $(296 / 296)$ of the DNA samples by endpoint PCR (Fig. 4).

\section{Discussion}

In this study, two DNA isolation methods from LBC samples were tested to compare their efficacies to yield good quality and quantity of DNA. Results demonstrated that the manual isolation of DNA from LBC is more effective than automated isolation under those conditions.

Initial handling and proper conservation of valuable DNA samples represent critical steps for the efficient utilization of LBC samples as the starting material for biomarker discovery. ${ }^{10}$ Biobanking and biospecimen science studies have emerged as a global priority in view of the critical importance of preanalytical precautions and their relevance in omics research for biomarker discovery. ${ }^{11}$ Nevertheless, studies addressing the QC of LBC samples are limited. ${ }^{12-17}$

Boulet et al. in 2008 demonstrated that the recovery of nucleic acids from cytology was possible even when a cytology sample had been stored for up to 10 years (archival smears), with all samples providing DNA suitable for PCR amplification with amplicons up to $400 \mathrm{bp} .{ }^{14}$ These studies demonstrated that long-term stored LBC samples are stable for the isolation of these nucleic acids. In this study, we chose a short amplicon; however, a long-range PCR should be designed for those downstream applications where less degraded DNA is required.

Serrano et al. ${ }^{18}$ isolated DNA, RNA, and proteins from LBC resuspended in saline solution buffer and concluded that preservation solutions (PAXgene ${ }^{\mathrm{TM}}$ or PreservCyt) can influence integrity and yield. In addition, the suitability of archived LBC cytological samples for molecular biology analyses has been investigated. In a study of 8-yearold samples stored at room temperature in PreservCyt solution, degradation of DNA by analysis of $\beta$-globin amplification and cytological nuclear preservation features were time-dependent, declining with increasing storage time. ${ }^{19}$ In this study, we demonstrated that storage time of LBC samples in PreservCyt for several weeks is safe at $4^{\circ} \mathrm{C}$. This methanolbased preservation solution is intended for ThinPrep Pap ${ }^{\mathrm{TM}}$ testing, even if kept between $15^{\circ} \mathrm{C}\left(59^{\circ} \mathrm{F}\right)$ and $30^{\circ} \mathrm{C}\left(86^{\circ} \mathrm{F}\right)$ and for up to 6 weeks. ${ }^{20}$ Notably, PreservCyt is used in routine clinical practice with the Hybrid Capture 2 ( $\mathrm{HC} 2)$ for $\mathrm{CC}$ screening, and it is also provided by Mexico's National Health Social Security System. ${ }^{21}$

The nucleic acid degradation evidenced by the smears in the gel lanes in Figure 2 can be explained by autolysis that occurs during normal epithelial cell maturation and changes that occurred after exfoliation. ${ }^{12,15,22}$

More recently, LBC studies have focused on differences between sampling devices, such as Cervex Brush ${ }^{\circledR}$ versus Cervex Brush ${ }^{\circledR}$ Combi, without having identified differences in DNA yield. ${ }^{23}$ Similarly, in this study, we did not identify significant differences in overall yield between two different brush types (comparison for DNA yield $p<0.6711$; Table 1, section b); significance was established when the manual versus automated DNA isolation from an LBC using the Colpotre $\left(p<0.0022^{* *}\right.$; Table 1 , section $\left.c\right)$ and the Rovers $(p<0.0445$; Table 1 , section $d)$. Colpotre is a Mexicanmade brush, similar to the Cervex Brush, but is approximately 
Table 1. DNA Yield from Liquid-Based Cytology Samples

\begin{tabular}{|c|c|c|c|c|c|c|}
\hline \multicolumn{2}{|c|}{ (a) Type of isolation: manual vs. automated } & \multicolumn{2}{|c|}{ Manual $(n=233)$} & \multicolumn{2}{|c|}{ Automated $(n=63)$} & $\mathrm{p}$-Value \\
\hline \multicolumn{2}{|l|}{ DNA yield $(\mu \mathrm{g})$} & \multicolumn{2}{|c|}{$22.81 \pm 1.92$} & \multicolumn{2}{|c|}{$9.96 \pm 1.11$} & $<0.0003 * *$ \\
\hline Purity $260 / 280$ & & \multicolumn{2}{|c|}{$1.83 \pm 0.02$} & \multicolumn{2}{|c|}{$1.81 \pm 0.02$} & $<0.6144$ \\
\hline Purity $260 / 230$ & & \multicolumn{2}{|c|}{$1.29 \pm 0.04$} & \multicolumn{2}{|c|}{$1.41 \pm 0.09$} & $<0.2219$ \\
\hline \multicolumn{2}{|c|}{ (b) Type of brush: Colpotre ${ }^{\circledR}$ vs. Rovers ${ }^{\circledR}$} & \multicolumn{2}{|c|}{ Colpotre $(n=261)$} & \multicolumn{2}{|c|}{ Rovers $(n=35)$} & $\mathrm{p}$-Value \\
\hline DNA yield $(\mu \mathrm{g})$ & & \multirow{2}{*}{\multicolumn{2}{|c|}{$\begin{array}{r}20.11 \pm 1.67 \\
1.83 \pm 0.02\end{array}$}} & \multicolumn{2}{|c|}{$18.04 \pm 4.55$} & $<0.6711$ \\
\hline Purity $260 / 280$ & & & & $1.81 \pm($ & & $<0.7181$ \\
\hline Purity $260 / 230$ & & \multicolumn{2}{|c|}{$1.32 \pm 0.04$} & \multicolumn{2}{|c|}{$1.26 \pm 0.11$} & $<0.6353$ \\
\hline \multicolumn{2}{|c|}{ (c) Colpotre brush: manual vs. automated } & \multicolumn{2}{|c|}{ Manual $(n=209)$} & \multicolumn{2}{|c|}{ Automated $(n=52)$} & $\mathrm{p}$-Value \\
\hline \multicolumn{2}{|l|}{ DNA yield $(\mu \mathrm{g})$} & \multicolumn{2}{|c|}{$22.75 \pm 2.03$} & \multicolumn{2}{|c|}{$9.88 \pm 1.28$} & $<0.0022 * *$ \\
\hline \multicolumn{2}{|c|}{ (d) Rovers brush: manual vs. automated } & \multicolumn{2}{|c|}{ Manual $(n=24)$} & \multicolumn{2}{|c|}{ Automated $(n=11)$} & p-Value \\
\hline \multicolumn{2}{|l|}{ DNA yield $(\mu \mathrm{g})$} & \multicolumn{2}{|c|}{$24.18 \pm 6.25$} & \multicolumn{2}{|c|}{$4.62 \pm 1.37$} & $<0.0445^{*}$ \\
\hline \multirow{2}{*}{$\begin{array}{l}\text { (e) Type of isolation } \\
\text { and brushes }\end{array}$} & \multicolumn{3}{|c|}{ Manual $(n=233)$} & \multicolumn{3}{|c|}{ Automated $(n=63)$} \\
\hline & Colpotre $(n=209)$ & Rovers $(n=24)$ & $p$ value & Colpotre $(n=52)$ & Rover & $\mathrm{p}$-Value \\
\hline DNA yield $(\mu \mathrm{g})$ & $22.65 \pm 2.03$ & $24.18 \pm 6.25$ & $<0.8094$ & $9.88 \pm 1.28$ & & $<0.0735$ \\
\hline Purity $260 / 280$ & $1.83 \pm 0.02$ & $1.83 \pm 0.02$ & $<0.9709$ & $1.82 \pm 0.02$ & & $<0.4083$ \\
\hline Purity $260 / 230$ & $1.29 \pm 0.04$ & $1.31 \pm 0.14$ & $<0.8646$ & $1.46 \pm 0.10$ & 1.15 & $<0.2232$ \\
\hline
\end{tabular}

Data are presented as the MEAN \pm SEM. $* p \leq 0.05, * * p \leq 0.01$, and $* * * p \leq 0.001$ values (bold) were considered statistically significant. The yield was generated from the first $100 \mu$ l eluted nucleic acids.

10 times less expensive than the Rovers Cervex Brush (retail cost in Mexico 0.25 USD and 2.57 USD, respectively). Therefore, according to this study, we believe that the two brushes were equally effective with regard to DNA yields, despite the differences in price.

To reduce operator-induced variations and more readily standardize throughput, we also tested a benchtop automated sample preparation machine (Qiacube; Qiagen), a low-throughput instrument that processes up to 12 samples per run. Automated protocols can be an alternative for more standardized, reproducible, and efficient protocols designated especially for high-throughput analyses, reducing hands-on time.

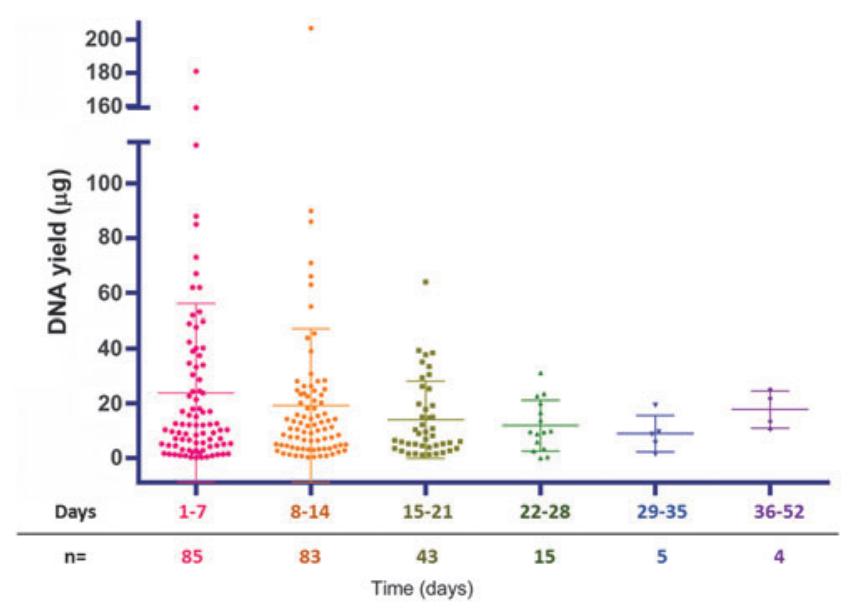

FIG. 3. Effect of storage time before isolation of DNA from LBC samples. No significant differences were observed $(p<0.3128)$.
As illustrated in Figure 1, the standard protocol for the automated method does not include the optional centrifugation spin to dry the column and prevent the carryover of ethanol in the DNA elution step; moreover, we did not find a statistically significant difference between manual and automated methods with respect to DNA purity. Furthermore, in the automated protocol, there is no incubation time before the DNA elution, which can result in low nucleic acid yield because DNA is still bound to the column membrane. ${ }^{24}$ Additionally, the centrifugation speed on the Qiacube automated method was only $12,000 \mathrm{~g}$, whereas in the manual method, centrifugation was performed at 20,000 $\mathrm{g}$. Even though the incubation step could not be performed by the automated method, a considerable amount of DNA was obtained. It is important to mention if the user needs a specific protocol for the automated method, the company can design it based on the user's requirements.

In this study, and as judged by DNA yield measurements, manual isolation resulted in greater yields, and this finding is in agreement with previous reports. ${ }^{25,26}$ However, the difference in yields may be attributed to the larger sample size for the manual method versus the automated method. Even if this method was superior, the advantages of the automation cannot be ignored and the choice of the DNA isolation method should be based on the workflow of each biobank.

Spectrophotometry is a traditional and economically convenient method of quantifying DNA in molecular biology laboratories due to its accessibility and also in biobank studies. ${ }^{27}$ However, other methods such as fluorometry by Qubit $^{\mathrm{TM}}$, have proven more reliable due to the specificity for double-stranded DNA. All the yield comparisons shown in Table 1 were performed based on fluorometry, and all the 
FIG. 4. Amplification of $\beta$-globin gene region from DNA isolated from LBC samples. Lane L: DNA ladder; Lane 1: negative control; Lanes 2-18: amplicon DNA of LBC samples; Lane 19: positive control amplicon DNAg previously known; Conditions: $8 \mu \mathrm{L}$ of amplicon DNA in agarose gel at $2 \%$ at 95 volts during 90 minutes.

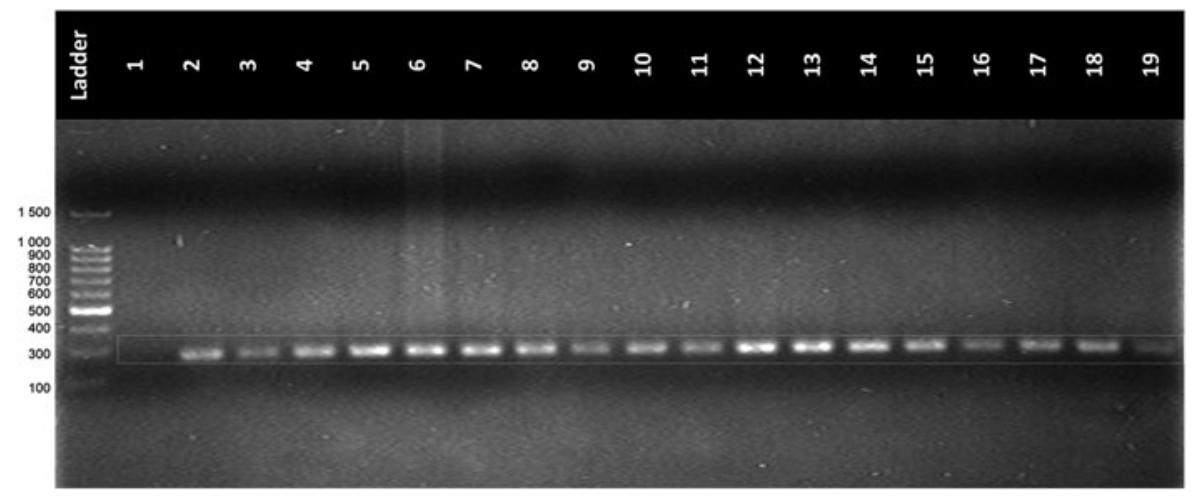

purity comparisons were performed based on spectrophotometry.

In this study, we obtained average DNA yields of $22.81 \mu \mathrm{g}$ $( \pm 1.92)$ and $9.96 \mu \mathrm{g}( \pm 1.11)$ using the manual and automated isolation methods, respectively, from an LBC sample, and reasonable integrity of DNA was verified, as seen in the prominence of a high molecular band (Fig. 2). Most traditional clinical molecular pathology assays are designed considering the degradation of DNA, rendering fragments of lengths varying between 100 and $400 \mathrm{bp}$, and typically require less than $50 \mathrm{ng}$ per analysis. However, the new technologies use significantly less DNA. In this study, we were able to obtain a considerable amount of DNA with both isolation methods.

Other general considerations on the isolation of nucleic acids are the dependent variables of the patient, such as the phase of her menstrual cycle, and those on the nurse/doctor, such as her/his skill to collect the sample.

The primary responsibility of biobanks is to collect biospecimens that truly represents features of the local population. ${ }^{28} \mathrm{CC}$ is the fourth leading cause of cancer death in women, with 311,000 worldwide deaths, and is the second leading cause of cancer death in women in Mexico with 4,121 deaths. ${ }^{29}$ Europe has a Cervical Cytology Biobank, which is a resource for molecular epidemiology and for evaluating $C C$ screening and intervention approaches. ${ }^{16,28,30}$ Currently, LBC is used for CC screening. When LBC is used in combination with NGS technology, it can be beneficial in developing early detection methods in other gynecological cancers. Since there are no early detection biomarkers currently known that are specific enough to detect ovarian and endometrial cancers, these two cancers have started to gain more attention given their lethality.

For these reasons, our work represents a guide to QC for collecting LBC samples and stresses the impact of good control of preanalytical conditions while obtaining samples (i.e., LBCs) in clinics far from a laboratory, to favor their quality as starting material for biomarkers discovery in the fight against the feared gynecological cancers.

\section{Authors' Contributions}

I.G.D.-V.: Conceptualization, patient recruitment, writingreview and editing, design of figures and table, data analysis, and interpretation; V.H.B.-O.: Patient recruitment, writingreview and editing; L.G.-A.: review and editing; A.A.P.-M.: review and editing; M.L.G.-R.: review and editing; G.I.M.-G.: Patient recruitment, review and editing; S.C.-H.: Patient recruitment, review and editing; D.H.M.-L.: Patient recruitment, review and editing; O.V.-G.: Patient recruitment, review and editing; D.F.C.: Patient recruitment, writing-review and editing; H.A.B.S.: Conceptualization, writing-review and editing, funding, and responsible for the overall content.

\section{Acknowledgments}

The authors express their appreciation thanks to Minerva Conejo and Tania Melchor for their assistance in sample collection, to Dr. Victor M. Treviño-Alvarado for assistance with statistical analysis, and John A. Martignetti and Lisa Arrigo for their insightful advice to improve the article.

\section{Author Disclosure Statement}

The authors declare no conflicts of interest in carrying out this research.

\section{Funding Information}

This work was partially supported by Mexico's National Council of Science and Technology (CONACYT) to our National Laboratory of Specialized Services of Research, Development, and Innovation for Pharma and Biotech Industries (LANDSEIDI); CONACYT Great National Health Problems Grant \#247850 and CONACYT Nationals Laboratories \#LN132017-271386 to H.A.B.S.

\section{References}

1. Mulford D. Alternatives to the traditional Papanicolaou (Pap) Smear - Liquid Based Cytology (LBC). Lab Med 2003;34: 129-131.

2. Traut HF, Papanicolaou GN. Cancer of the uterus: The vaginal smear in its diagnosis. Cal West Med 1943;59:121-122.

3. Haghighi F, Ghanbarzadeh N, Ataee M, Sharifzadeh G, Mojarrad JS, Najafi-Semnani F. A comparison of liquidbased cytology with conventional Papanicolaou smears in cervical dysplasia diagnosis. Adv Biomed Res 2016;5:162.

4. Kinde I, Bettegowda C, Wang Y, et al. Evaluation of DNA from the Papanicolaou test to detect ovarian and endometrial cancers. Sci Transl Med 2013;5:167ra4.

5. Wang Y, Li L, Douville C, et al. Evaluation of liquid from the Papanicolaou test and other liquid biopsies for the detection of endometrial and ovarian cancers. Sci Transl Med 2018;10: pii: eaap8793.

6. Garza-Rodríguez ML, Pérez-Maya AA, Monsivais-Ovalle DE, Velázquez-Vadillo JF, Barrera-Saldaña HA. El Bio- 
banco Institucional como pilar de las ciencias médicas. Salud Publica Mex 2016;58:483-489.

7. Mendy M, Lawlor RT, van Kappel AL, et al. Biospecimens and biobanking in global health. Clin Lab Med 2017;38: 183-207.

8. Bongiovanni A, Colotti G, Liguori GL, et al. Applying quality and project management methodologies in biomedical research laboratories: A public research network's case study. Accredit Qual Assur 2015;20:203-213.

9. Ravagnani FG, Saidemberd DM, Faria ALC, Sartor SB, Oliveira D, Catharino RR. Quality control of biomarkers: From the samples to data interpretation. In: Latest Research into Quality Control. London, United Kingdom, InTech; 2012. p. 514.

10. Haque K, Pfeiffer R, Beerman M, Struewing J, Chanock S, Bergen A. Performance of high-throughput DNA quantification methods. BMC Biotechnol 2003;3:20.

11. Krishnamurthy S. Biospecimen repositories and cytopathology. Cancer Cytopathol 2015;123:152-161.

12. Klaassen I, Copper MP, Brakenhoff RH, Smeets SJ, Snow GB, Braakhuis BJM. Exfoliated oral cell messenger RNA: Suitability for biomarker studies. Cancer Epidemiol Biomarkers Prev 1998;7:469-472.

13. Tomomi F, Asano A, Shimada K, Tatsumi Y, Obayashi C, Konishi N. Evaluation of RNA and DNA extraction from liquid-based cytology specimens. Mol Cytopathol Eval 2016; 44:833-840.

14. Boulet GA, Horvath CA, Berghmans S, et al. Cervical cytology biobanking: Quality of DNA from archival cervical Pap-stained smears. J Clin Pathol 2008;61:637-641.

15. Habis AH, Vernon SD, Lee DR, Verma M, Unger ER. Molecular quality of exfoliated cervical cells: Implications for molecular epidemiology and biomarker discovery. Cancer Epidemiol Biomarkers Prev 2004;13:492-496.

16. Arbyn M, Van Veen E Ben, Andersson K, et al. Cervical cytology biobanking in Europe. Int J Biol Markers 2010;25: $117-125$.

17. Tarkowski TA, Rajeevan MS, Lee DR, Unger ER. Improved detection of viral RNA isolated from liquid-based cytology samples. Mol Diagnosis 2001;6:125-130.

18. Serrano ML, Romero Rojas AE, Sánchez Gómez M, Bravo MM. Extracción de ADN, ARN proteínas de células cervicales provenientes de cepillados cervicales tomados para citología cérvico-uterina. Rev Colomb Cancerol 2006;10: 117-124.

19. Castle PE, Solomon D, Hildesheim A, et al. Stability of archived liquid-based cervical cytologic specimens. Cancer Cytopathol 2003;99:89-96.

20. Hologic. ThinPrep 2000 System, Instructions for use. Marlborough, USA: Hologic; 2018.

21. PAHO. Integrating HPV Testing in Cervical Cancer Screening Program: A Manual for Program Managers. Washington, DC: PAHO; 2016: 68.

22. Bhattacharya P, Pappelis A. Changes in nucleic acid and protein content in nuclei of human. Mech Ageing Dev 1984; 27:135-142.
23. Depuydt CE, Benoy IH, Bailleul EJ, Vandepitte J, Vereecken AJ, Bogers JJ. Improved endocervical sampling and HPV viral load detection by Cervex-Brush ${ }^{\circledR}$ Combi. Cytopathology 2006;17:374-381.

24. Qiagen AllPrep ${ }^{\circledR}$ DNA/RNA/miRNA Universal Handbook. USA: Qiagen: 2016.

25. Riemann K, Adamzik M, Frauenrath S, et al. Comparison of manual and automated nucleic acid extraction from whole-blood samples. J Clin Lab Anal 2007;21: 244-248.

26. Mathieson W, Guljar N, Sanchez I, Sroya M, Thomas GA. Extracting DNA from FFPE tissue biospecimens using user-Friendly automated technology: Is there an impact on yield or quality? Biopreserv Biobank 2018;16: 191-199.

27. Guadagni F, Morte D Della, Ludovici G, et al. Preanalytical procedures for DNA studies: The experience of the interinstitutional multidisciplinary BioBank (BioBIM). Biopreserv Biobank 2011;9:35-45.

28. Perskvist N, Björklund C, Dillner J. A Complex intervention for workflow enhancement at the swedish cervical cytology biobank. Biopreserv Biobank 2014;12: 69-73.

29. Bray F, Ferlay J, Soerjomataram I. Global cancer statistics 2018: GLOBOCAN estimates of incidence and mortality worldwide for 36 cancers in 185 Countries. CA Cancer J Clin 2018;68:394-424.

30. Perskvist N, Norman I, Eklund C, Litton J-E, Dillner J. The swedish cervical cytology biobank: Sample handling and storage process. Biopreserv Biobank 2013;11:19-24.

Address correspondence to: Hugo A. Barrera Saldaña, PhD National Laboratory of Specialized Services of Research, Development, and Innovation for Chemical and Biotechnological Drugs at Innbiogem

SC Boulevard

Puerta del Sol \#1005

Colinas de San Jerónimo

C.P. 64630 Monterrey N.L. México

E-mail: habarrera@gmail.com

David F. Cantú De León, MD, MSc, PhD Subbdireccion de Investigación Clínica Instituto Nacional de Cancerologia

Av. San Fernando

No. 22 Belisario Domínguez Secc 16 CP 14080 Ciudad de México

México

E-mail: dcantude@gmail.com 